\title{
Editorial: New insights in vocational education and training
}

\author{
Per Andersson*, Song-ee Ahn*, \\ Hedvig Skonhoft Johannesen**, \\ Johanna Köpsén* \& Arnt Louw***
}

*Linköping University, Sweden

(per.andersson@liu.se, song.ee.ahn@liu.se, johanna.kopsen@liu.se)

**OsloMet - Oslo Metropolitan University, Norway (hjohanne@oslomet.no) ***Aalborg University, Denmark (avl@hum.aau.dk)

This is the second issue of the Nordic Journal of Vocational Education and Training in 2021. In this issue we present six articles - five peer-reviewed research articles and one magazine article, representing three of our Nordic countries. Three of the articles are contributions from Norway, two from Denmark and one from Sweden. In our journal we want to provide new insights and discussions on different aspects of vocational and professional education and training. The present contributions cover topics that particularly concern the vocational education and training (VET) teacher, such as the teacher's role, teacher education, professional development, and collaboration. For example, two studies from health care education discuss the teacher's role in VET for adults, with many immigrant students and where communication and language become central, and the teachers' experience of a 'career paradox' among students - that is, how many students are focused on further studies rather than a future in health care work.

\section{The six articles}

The first research article is from Norway - One size fits nobody: En casestudie av yrkesfaglæreres deltakelse i kompetanse-utviklingsarbeid i videregående skole (One size fits nobody: A case study of vocational education and training teachers' participation in professional development projects in upper secondary school) by Julie 
Klovholt Leonardsen. The study draws on ethnographic case data from observations and interviews with vocational teacher's related to a professional developmental project of student assessment literacy. The findings show that for vocational teachers to improve their assessment literacy the projects must seem vocational relevant, have vocational perspectives on assessment, and finally be situated in a learning-oriented culture.

The second research article is "Det är klart de vet vad uppgivenhet betyder": Kommunikation och språk $i$ vård- och omsorgsutbildning på komvux ('Of course they know what resignation means': Communication and language in adult care education) is a study from Sweden by Sara Hultqvist and Katarina Hollertz. It concerns the teachers' role and work in Swedish vocational health care education for adults, where half of the students are immigrants. The article highlights the teachers' role as street level bureaucrats, which means that the teachers are considered the executors of state-formulated educational and social policies. The teachers are required to supply the labour market, here the field of elderly care, with competent staff and to offer individually tailored education for the students. This study highlights the importance of communication and language in health care education and in the elderly care practice. The results show that communication and language have central roles in different ways and the teachers use different strategies to enact sometimes contradictory policies in the teaching practice.

The third research article discusses the career paradox experienced by vocational teachers when teaching at the health-care worker programme at the upper secondary level. Yrkesfaglærerens paradoks: Utdanne til fagarbeid eller videre studier? (The vocational teacher's paradox: Educate for professional work or further studies?) is written by Else Marie Johansen from Norway. The article addresses vocational teacher's reflections about the vocational motivation of the VET students at the health-care worker programme and shows that many of the students have other future plans than training to become health-care workers. The data comes from group interviews and the theoretical foundation lies in motivation theory, self-efficacy and communities of practice. The findings reveal that the motivations of the students are complex and therefore the teachers in the study find it difficult to differentiate teaching at the right level - resulting in that the teachers teach at a more general level, possibly diminishing the importance of the profession in their teaching.

The fourth research article - Samarbeid og lærerprofessionalitet (Collaboration and teacher professionalism) - by Stein Rafoss and Hilde Witsø from Norway is based on a research project carried out among 10 VET teacher students in practical pedagogical education for vocational teachers in Norway. The article concerns the importance of collaboration in the development of teacher professionalism through the research question: How can group collaboration between vocational education and training (VET) students contribute to the development of their teacher professionalism? The aim of the article is to understand how group 
collaboration can be organised to support the significance of collaboration as a VET teacher. The article draws on Dale's theory of teacher professionalism. Based on interviews with the VET teacher students as well as analysis of the internship documents they produced during the internship period it is concluded that their internship made it possible for the students to talk and reflect on didactic questions related to Dale's three areas of expertise.

In the fifth and final research article of this issue Britta Møller, Charlotte Wegener, Anne-Birgitte Rohwedder, Anja Overgaard Thomassen and René Dybdal from Denmark make a scoping review of research in social and health care education. In the article Uddannelse til ældrepleje: Et scoping review af læring $i$ dansk social- og sundhedsuddannelse (Elderly care education: A scoping review of learning in Danish social and health care education) the authors present an overview of existing research in the Danish context wishing to initiate a Nordic exchange of research-based knowledge about elderly care education. They conclude that few of the examined Danish studies focus on the social and health care educational programmes from a learning perspective. The focus seems instead to be on the trainees in these programmes as learners.

The last article is a magazine article from Denmark. This article: Lxrerrollen der blev væk: Opbygningen af et transformativt lærerideal (The disappearance of the vocational teacher's role: The construction of a transformative teacher ideal), is written by Tobias Kidde Skov. The author discusses the role of the VET teacher and in light of the rising tendency to describe the teacher's role as both supervisor, facilitator, motivator and consultant, raises the question if the role of the vocational teachers needs another teacher's ideal. The article draws theoretically on the work of Gert Biesta, Hartmut Rosa and Andrea English and discusses a transformative teaching ideal as a way of understanding the role of the VET teacher. It is concluded that such a transformative understanding of the teacher role is a way to give back the original teaching task to the teacher as opposed to the current trend of constructivism. 